\title{
PRIJEDLOG IZMJENE ODREDABA ZAKONA O TRŽIŠTU ELEKTRIČNE ENERGIJE O DIJELJENJU POSLOVNIH PROSTORA, IT OPREME TE IT SUSTAVA KAO I KORIŠTENJU ISTIH PRUŽATELJA IT USLUGA I ISPORUČITELJA IT OPREME IZMEĐU NEOVISNOG OPERATORA PRIJENOSA I OSTALIH SUBJEKATA VERTIKALNO INTEGRIRANE STRUKTURE
}

Doc. dr. sc. Tomislav Jakšić*

Daša Vrzić, mag. iur.**

\author{
UDK 339.923:061.1](4)EU:621.31 \\ https://doi.org/ 10.30925/zpfsr.41.3.2 \\ Ur.: 17. srpnja 2020. \\ Pr.: 15. rujna 2020. \\ Izvorni znanstveni rad
}

\begin{abstract}
Sažetak
Neovisni operator prijenosa jedan je od tri moguća načina odvajanja operatora prijenosnog sustava od ostalih subjekata u vertikalno integriranoj strukturi. Hrvatski operator prijenosnog sustava odvojen je od vertikalno integrirane strukture upravo primjenom modela neovisnog operatora prijenosa. Imajući $u$ vidu skoru potrebu širih izmjena $i$ dopuna domaćega zakonodavnog okvira koji uređuje tržište električne energije u radu se kritički razmatraju određeni problematični aspekti takvog odvajanja, primjerice, pravila o dijeljenju informacijskih sustava (softvera), računalne, mrežne i sigurnosne infrastrukture (hardvera), kao i korištenju usluga istih savjetnika i vanjskih izvođača. Analizom postojećih europskih pravnih pravila kao $i$ zakonskih rješenja usporedivih država članica, rad pruža konkretne de lege ferenda prijedloge za moguće buduć pravno uređenje razmatranih aspekata predmetnog odvajanja neovisnog operatora prijenosa od ostatka vertikalno integrirane strukture.
\end{abstract}

Ključne riječi: neovisni operator prijenosa; tržište električne energije; operator prijenosnog sustava; povezana društva.

\section{1. $U V O D$}

Direktiva 2009/72/EZ Europskog parlamenta i Vijeća od 13. srpnja 2009. o zajedničkim pravilima za unutarnje tržište električne energije i stavljanju izvan snage Direktive 2003/54/EZ (u daljnjem tekstu: Direktiva 2009/72/EZ) nastaje radi

* Dr. sc. Tomislav Jakšić, docent, Pravni fakultet Sveučilišta u Zagrebu; tomislav.jaksic@pravo. hr.

** Daša Vrzić, mag. iur., odvjetnica u Zagrebu; dasa.vrzic@gmail.com. 
sprječavanja zloupotrebe i narušavanja tržišnog natjecanja između sudionika na tržištu električne energije ostalih subjekata vertikalno integrirane strukture (npr. distributera i proizvođača električne energije) nad ovisnim operatorom prijenosnog sustava koji upravlja prijenosnom mrežom. ${ }^{1}$ Do takve je zloupotrebe najčešće dolazi od strane vladajućeg subjekta korištenjem gospodarski osjetljivih informacija kojima raspolaže operator prijenosnog sustava o drugim tržišnim takmacima, zbog diskriminatornog postupanja subjekata vertikalno integrirane strukture prema potencijalnim tržišnim takmacima kojima je za obavljanje vlastite djelatnosti potreban pristup prijenosnoj mreži, a konačno i zbog manjka interesa vladajućeg subjekta za ulaganja u razvoj prijenosne mreže za dobrobit cjelokupnog tržišta i svih korisnika mreže. ${ }^{2}$

Direktiva 2009/72/EZ stoga je predvidjela tri modela odvajanja operatora prijenosnog sustava od ostalih subjekta u vertikalno integriranoj strukturi: vlasničko odvajanje (engl. Ownership Unbundling OU), neovisni operator sustava (engl. An Independent System Operator ISO) i neovisni operator prijenosa (engl. An Independent Transmission Operator ITO). ${ }^{3}$ Uz navedene modele predviđena je i posebna iznimka propisana čl. 9. st. 9. Direktive 2009/72/EZ, kao, tzv. model ITO+. ${ }^{4}$

U hrvatski pravni poredak Direktiva 2009/72/EZ je transponirana u brojne propise (zakone, pravilnike i uredbe). ${ }^{5}$ Dio koji se odnosi na modele odvajanja operatora prijenosnog sustava od ostalih subjekta u vertikalno integriranoj strukturi uređen je Zakonom o tržištu električne energije iz 2013. (u daljnjem tekstu: ZoTEE). ${ }^{6}$ Nakon dvije godine primjene pravila o neovisnom operatoru prijenosa Europska komisija pozitivno je procijenila učinke njihove primjene u državama članicama, navodeći kako takva pravila funkcioniraju u praksi te pružaju dostatnu razinu odvajanja operatora prijenosnog sustava od ostalih subjekta $\mathrm{u}$ vertikalno integriranoj strukturi. ${ }^{7}$ Tomu u prilog govori i sadržaj nove Direktive 2019/944 Europskog parlamenta i Vijeća od 5. lipnja 2019. o zajedničkim pravilima za unutarnje tržište električne energije i izmjeni

1 Direktiva 2009/72/EZ Europskog parlamenta i Vijeća od 13. srpnja 2009. o zajedničkim pravilima za unutarnje tržište električne energije i stavljanju izvan snage Direktive 2003/54/ EZ, SL 211, 14.8.2009.

2 European Commission, An Energy Policy for Europe, 10 January 2007, COM (2006) 841 final, $10-11$.

3 Tako vidi čl. 9. Direktive 2009/72/EZ za vlasničko odvajanje, čl. 13. i 14. Direktive 2009/72/EZ za neovisnog operatora sustava te čl. 17. do 23. Direktive 2009/72/EZ za neovisnog operatora prijenosa. Više o pojedinim modelima odvajanja vidi pod „2. Tri modela odvajanja operatora prijenosnog sustava“.

4 Model ITO+ osmišljen je kao iznimka od općih pravila koja obvezuju države članice u primjeni nekog od ponuđenih modela odvajanja operatora prijenosnog sustava od ostalih subjekata vertikalno integrirane strukture. Više o tome vidi CEER, Status Review on the Implementation of Transmission System Operators' Unbundling Provisions of the 3rd Energy Package, CEER Status Review, Ref: C15-LTF-43-04, 1 April 2016, Updated on 28 April 2016, 33.

5 Tako, primjerice, Zakonom o regulaciji energetskih aktivnosti, Narodne novine, br. 120/12., 68/18. i Uredbom o kriterijima za stjecanje statusa ugroženog kupca energije iz umreženih sustava, Narodne novine, br. 95/15.

6 Zakon o tržištu električne energije, Narodne novine, br. 22/13., 102/15., 68/18., 52/19.

7 European Commission, Commission Staff Working Document - Report on the ITO Model, 13 October 2014, SWD(2014) 312 final, 6-7. 
Direktive 2012/27/EU (u daljnjem tekstu: Direktiva 2019/944). ${ }^{8}$ Predmetnom se direktivom mijenja veći broj odredaba Direktive 2009/72/EZ, no sadržajno se ne dira u dijelove koji se odnose na neovisnog operatora prijenosa. ${ }^{9}$ Drugim riječima, odredbe koje se odnose na neovisnog operatora prijenosa iz Direktive 2009/72/EZ sadržajno su istovjetne odredbama o neovisnom operatoru prijenosa u Direktivi 2019/944.

Pravila koja se odnose na neovisnog operatora prijenosa uređena su čl. 18. do 21. ZoTEE-a. Pritom je domaći zakonodavac pri transponiranju Direktive 2009/72/ EZ u hrvatski pravni sustav pretežno kopirao sadržaj odredaba direktive o neovisnom operatoru prijenosa u odredbe ZoTEE ne iskoristivši slobodu koje države članice imaju pri transponiranju takvog sekundarnog prava Europske unije u nacionalno pravo. ${ }^{10}$ Za razliku od domaćega zakonodavca, odredbe direktive o neovisnom operatoru prijenosa u pojedinim državama članicama, koje također primjenjuju model neovisnog operatora prijenosa, transponirane su na način koji detaljno uređuje opća rješenja direktive. Zakonodavna rješenja tih država članica (npr. Njemačke, Francuske) u pravilu su kvalitetnija jer je transponiranje učinjeno na način koji uvažava posebnosti nacionalnoga pravnog sustava i potreba pravnog prometa uz očuvanje cilja i svrhe pravnih rješenja direktive.

Republika Hrvatska, kao i druge države članice, do kraja 2020. moraju transponirati u svoja nacionalna prava Direktivu 2019/944 koja zamjenjuje Direktivu 2009/72/EZ. Pri takvom transponiranju te izmjenama i dopunama ZoTEE-a ne treba propustiti priliku jasnijeg i detaljnijeg uređenja pravnih rješenja o neovisnom operatoru prijenosa koja su se u praksi pokazala pretjerano ograničavajućim i nepraktičnim. Takva se pravila odnose na zabranu zajedničkoga korištenja poslovnih prostora, IT opreme, IT sustava, pružatelja IT usluga i isporučitelja IT opreme između neovisnog operatora prijenosa i ostalih subjekata vertikalno integrirane strukture.

Shodno tomu rad je podijeljen na četiri dijela. Pritom se nakon ovog uvodnog dijela općenito obrazlažu tri modela odvajanja operatora prijenosnog sustava od ostalih subjekata vertikalno integrirane strukture. Potom se razmatra odredba čl. 17. st. 5. Direktive 2009/72/EZ te odgovarajuće odredbe njemačkog i francuskog prava, a zaključno se pružaju i de lege ferenda prijedlozi novih odredaba ZoTEE-a kojima se otklanjaju takvi nedostaci uz istodobno očuvanje cilja i svrhe razmatranih rješenja Direktive 2009/72/EZ i Direktive 2019/944.

8 Direktiva 2019/944 Europskog parlamenta i Vijeća od 5. lipnja 2019. o zajedničkim pravilima za unutarnje tržište električne energije i izmjeni Direktive 2012/27/EU, SL 158, 14.6.2019.

9 Za to kako se je potrebno promijeniti veći broj odredaba Direktive 2009/72/EZ vidi općenito t. 1. preambule Direktive 2019/944. Za usporedbu pravila o neovisnom operatoru prijenosa usporedi, primjerice, odredbe čl. 17. i 18. Direktive 2009/72/EZ te odredbe čl. 46. i 47. Direktive 2019/944.

10 Tako, primjerice, usporedi čl. 17. st. 1. 2009/72/EZ i čl. 18. st. 3. ZoTEE, čl. 17. st. 5. 2009/72/ EZ i čl. 18. st. 7. ZoTEE-a. Direktive nemaju izravan učinak kao uredbe, ali stvaraju obvezu odgovarajućeg transponiranja u nacionalni pravni poredak. Svaka država članica pritom može odrediti način kojim će postići ciljeve koje nalaže direktiva jer, za razliku od uredbi, svrha direktive nije osiguravanje jedinstvene primjene prava u Europskoj uniji. To znači kako transponiranje europskog prava $u$ nacionalno pravo države članice nije potpuni sadržajni prijenos teksta direktive u nacionalni pravni poredak, već se dopušta oblikovanje sadržaja kojim se uvažavaju raznolikosti i posebnosti koje postoje u svakoj državi članici, a kojim se ujedno ostvaruju cilj i svrha direktive. 


\section{TRI MODELA ODVAJANJA OPERATORA PRIJENOSNOG SUSTAVA OD OSTALIH SUBJEKATA U VERTIKALNO INTEGRIRANOJ STRUKTURI}

Vlasničko odvajanje, kao najučinkovitiji način za provedbu odvajanja, temelji se na zabrani prema kojoj ista osoba ne može istodobno imati kontrolu nad subjektom koji obavlja funkciju proizvodnje ili opskrbe te kontrolu ili bilo koje pravo nad operatorom prijenosnog sustava ili nad samim prijenosnim sustavom te obratno. Drugim riječima, nakon vlasničkog odvajanja (npr. otuđenjem članskih udjela) operator prijenosnog sustava više nije dio vlasničke (vertikalno integrirane) strukture subjekta koji obavlja funkciju proizvodnje ili opskrbe.

Kod modela neovisnog operatora sustava, prijenosna mreža i druga infrastruktura prijenosnog sustava ostaje u vlasništvu vladajućeg subjekta vertikalno integrirane strukture, ali njome samostalno i neovisno upravlja drugo društvo koje je neovisno o takvoj vertikalno integriranoj strukturi (tzv. neovisni operator sustava).

U posljednjem modelu operator prijenosnog sustava ostaje dijelom vertikalno integrirane strukture (tzv. neovisni operator prijenosa). Zbog toga je europski zakonodavac odredio pravila usmjerena na postizanje potrebne financijske, pravne i operativne samostalnosti neovisnog operatora prijenosa u odnosu na ostatak vertikalno integrirane strukture. Kod tog modela, nije riječ o vlasničkom odvajanju operatora iz vertikalno integrirane strukture, već o uspostavi pravila usmjerenih na učinke koji odgovaraju učincima vlasničkog (strukturalnog) odvajanja, tzv. pravno odvajanje. ${ }^{11}$ Takve mjere ograničavaju primjenu uobičajenih pravila o povezanim društvima (npr. o vođenju poslova vladajućeg društva) na neovisnog operatora prijenosa kao ovisnog društva vertikalno integrirane strukture (npr. koncerna). ${ }^{12}$ Ova dodatna pravila teže učinkovito otkloniti mogući sukob interesa između ostalih subjekata vertikalno integrirane strukture i njihovih tržišnih takmaca (u opskrbi i proizvodnji električne energije) koji se koriste uslugama operatora prijenosnog sustava kao djela vertikalno integrirane strukture. Time se otklanjaju ili barem znatno oslabljuju negativni učinci prirodnog monopola na tržištu prijenosa električne energije. Navedeno znači i kako operator prijenosnog sustava ostaje u gospodarskom smislu dio vertikalno integrirane strukture te formalno u "vlasništvu“ vladajućeg subjekta takve strukture koji, primjerice, ima pravo na isplatu dobiti. ${ }^{13}$ Nakon pritiska Francuske i Njemačke ovaj je model odvajanja uvršten naknadno u prijedlog nacrta Direktive 2009/72/EZ. ${ }^{14}$

11 Frank Hölscher, u: EnWG Energiewirtschaftsgesetz, eds. Gabriele Britz, Johannes Hellermann i Georg Hermes, 3. Aufl. (München: C.H. Beck, 2015.), §10 EnWG Rbr. 2; Matthias Knauff, u: Energiewirtschaftsgesetz, ed. Martin Kment, 2. Aufl. (Baden-Baden: Nomos, 2019.), §10 EnWG Rbr. 1.

12 Franz Jürgen Säcker i Jochen Mohr, u: Berliner Kommentar zum Energierecht, Bd. 1 (Halbbd. 1), ed. Franz Jürgen Säcker, 4. Aufl. (Berlin: R\&W, 2019.), §10 EnWG Rbr. 1, 21.

13 Knauff, u: Energiewirtschaftsgesetz, §10 EnWG Rbr. 2.

14 Michael Dralle Tilman, Ownership Unbundling and Related Measures in the EU Energy Sector (Cham: Springer, 2018.), 26; Hölscher, u: EnWG Energiewirtschaftsgesetz, eds. Gabriele Britz, Johannes Hellermann i Georg Hermes, $\$ 10$ EnWG Rbr. 1. U tom smjeru vidi Säcker, Mohr, u: Berliner Kommentar zum Energierecht, $\$ 10$ EnWG Rbr. 6. 
Od ponuđenih modela, europski zakonodavac pružio je očitu prednost modelu potpunoga vlasničkog odvajanja kao najboljem za postizanje svrhe sadržane u odredbama predmetne direktive. ${ }^{15}$ Takav se model odvajanja primjenjuje u $70 \%$ država članica uključujući Italiju, Sloveniju, Dansku, Švedsku i Španjolsku. Model neovisnog operatora sustava primjenjuje se u $6 \%$ država članica, npr. u Rumunjskoj. Model neovisnog operatora prijenosa primjenjuje se u $12 \%$ država članica uključujući Hrvatsku, Mađarsku i Grčku. U tri države članice primjenjuju se kombinacije pojedinih modela (npr. Njemačka i Austrija primjenjuju model potpunoga vlasničkog odvajanja $\mathrm{s}$ modelom neovisnog operatora prijenosa). ${ }^{16}$

\section{PRAVILA O ZAJEDNIČKOM KORIŠTENJU POSLOVNIH PROSTORA, IT OPREME, IT SUSTAVA, PRUŽATELJA IT USLUGA I ISPORUČITELJA IT OPREME IZME円U NEOVISNOG OPERATORA PRIJENOSA I OSTALIH SUBJEKATA VERTIKALNO INTEGRIRANE STRUKTURE}

Imajući u vidu kako operator prijenosnog sustava kod modela neovisnog operatora prijenosa ostaje dijelom vertikalno integrirane strukture, Direktiva 2009/72/ EZ određuje brojna dodatna pravila usmjerena na osiguravanje financijske, pravne i operativne neovisnosti operatora prijenosnog sustava od ostalih subjekta vertikalno integrirane strukture. Ta su pravila općenito usmjerena na „odvajanje“ prijenosnog sustava iz vertikalno integrirane strukture (koncerna) radi jačanja transparentnosti te sprječavanja zloupotrebe i narušavanja tržišnog natjecanja subjekata koji pripadaju vertikalno integriranoj strukturi. ${ }^{17}$ Pravilima se tako, primjerice, teži uspostavi i održavanju slobodnog pristupa prijenosnom sustavu svim sudionicima na tržištu električne energije, uspostavi samostalnosti u određivanju jedinstvene tarife za pristup i korištenje prijenosnog sustava, sprječavanju otkrivanja povjerljivih i osjetljivih informacija drugim subjektima vertikalno integrirane strukture te onemogućavanju donošenja poslovodnih odluka koje narušavaju tržišno natjecanje na nacionalnom i zajedničkom (unutarnjem) tržištu. ${ }^{18}$ Drugim riječima, neovisni operator prijenosa upravlja, održava i razvija prijenosni sustav, samostalno djeluje na tržištu i slobodno ulazi u pravne odnose s trećima, uspostavlja i održava vlastite odjele za pružanje

15 To stoga što je samo onim državama članicama u kojima je na dan stupanja na snagu direktive operator prijenosnog sustava bio u vlasništvu subjekta vertikalno integrirane strukture dana mogućnost izbora drugih modela odvajanja. Tako vidi CEER, Status Review on the Implementation of Transmission System Operators' Unbundling Provisions of the 3rd Energy Package, CEER Status Review, Ref: C15-LTF-43-04, 1 April 2016, Updated on 28 April 2016, 9.

16 CEER, Status Review on the Implementation of Transmission System Operators' Unbundling Provisions of the 3rd Energy Package, CEER Status Review, Ref: C15-LTF-43-04, 1 April 2016, Updated on 28 April 2016, 13-14.

17 Tako sa stajališta usporedivoga njemačkog prava vidi Säcker, Mohr, u: Berliner Kommentar zum Energierecht, §10a EnWG Rbr. 1.

18 Tako sa stajališta usporedivoga njemačkog prava vidi Säcker, Mohr, u: Berliner Kommentar zum Energierecht, §10a EnWG Rbr. 2. 
usluga (računovodstvo, obrada podataka, kadrovska i pravna služba, IT odjel i sl.) te slobodno ulazi u zajedničke pothvate s drugim operatorima prijenosnog sustava, burzama električne energije i drugim sudionicima u cilju liberalizacije te razvoja nacionalnoga i regionalnog tržišta električne energije. ${ }^{19}$

Uz mjere usmjerene na osiguravanje dostatnih imovinskih i ljudskih sredstava, Direktiva 2009/72/EZ određuje i mjere usmjerene na osiguravanje samostalnosti u korištenju informacijskih sustava i informacijske infrastrukture u odnosu na ostale subjekte vertikalno integrirane strukture. Tako prema čl. 17. st. 5. Direktive operator prijenosnog sustava ne smije dijeliti sustave ili opremu informacijske tehnologije, fizičke prostore i sustave sigurnog pristupa s bilo kojim dijelom vertikalno integriranog poduzeća te koristiti iste savjetnike i vanjske ugovaratelje za sustave ili opremu informacijske tehnologije te sustave sigurnoga pristupa. Tom se odredbom nastoji osigurati operativna samostalnost neovisnog operatora prijenosa koju je moguće povrijediti kada drugi subjekti vertikalno integrirane strukture izravno ili neizravno pristupaju informacijskom sustavu ili infrastrukturi koju u obavljanju svoje djelatnosti koristi neovisni operator prijenosa. Osiguravanje samostalnosti neovisnog operatora prijenosa uspostavlja se i radi zaštite ostalih sudionika na tržištu električne energije koji se koriste uslugama neovisnog operatora prijenosa, a koji nisu dio vertikalno integrirane strukture kojoj pripada neovisni operator prijenosa.

Navedena odredba Direktive 2009/72/EZ istovjetna je odredbi čl. 46. st. 5. Direktive 2019/944 koja zamjenjuje Direktivu 2009/72/EZ. Drugim riječima, vezano za zahtjev za transponiranjem sadržaja Direktive 2019/944 u nacionalne propise država članica u odnosu na čl. 17. Direktive 2009/72/EZ ništa se ne mijenja prema onome što je već transponirano u nacionalni propis u tom pogledu (npr. ZoTEE). Pri transponiranju novoga sadržaja Direktive 2019/944 u nacionalno zakonodavstvo otvara se mogućnost detaljnijeg uređenja nepromijenjenih pravila o neovisnom operatoru prijenosa iz čl. 46. st. 5. Direktive 2019/944 radi prilagođavanja posebnostima na domaćem tržištu pružatelja IT usluga. ${ }^{20}$

\subsection{Njemačka poredbeno pravna rješenja}

Njemački zakonodavac transponirao je odredbu čl. 17. st. 5. Direktive 2009/72/ EZ u odredbe $\S 10$ a st. 5. i 6. Energiewirtschaftsgesetz (u daljnjem tekstu: EnWG). ${ }^{21}$ Pritom je nužno naglasiti kako njemački zakonodavac u trenutku pisanja ovoga rada još nije transponirao u svoje nacionalno pravo odredbe Direktive 2019/944 koje zamjenjuju odredbe Direktive 2009/72/EZ. Za očekivati je kako se transpozicija odredbe čl. 46. st. 5. Direktive 2019/944 neće razlikovati od postojećih zakonskih rješenja EnWG-a jer između tih odredaba i odgovarajuće odredbe Direktive 2009/72/ EZ sadržajno nema razlike.

19 Tako sa stajališta usporedivoga njemačkog prava vidi Säcker, Mohr, u: Berliner Kommentar zum Energierecht, §10 EnWG Rbr. 29-38; Knauff, u: Energiewirtschaftsgesetz, §10 EnWG Rbr. 6-9.

20 Prema čl. 71. Direktive 2019/944 transponiranje se mora provesti do 31. prosinca 2020.

21 Energiewirtschaftsgesetz vom 7. Juli 2005 (BGBl. I S. 1970, 3621), das zuletzt durch Artikel 3 des Gesetzes vom 17. Dezember 2018 (BGBl. I S. 2549) geändert worden ist. 
Odredbom §10a st. 5. EnWG-a uređena su pravila o zajedničkom korištenju informacijskih sustava i informacijske infrastrukture između neovisnog operatora prijenosa i drugih subjekata vertikalno integrirane strukture, a potom i pravila o korištenju usluga istih savjetnika ili vanjskih izvođača u pogledu takvih sustava $\mathrm{i}$ infrastrukture. Tako predmetna odredba određuje: Neovisni operator prijenosa mora se suzdržati od zajedničkog korištenja informacijskih sustava s vertikalno integriranim elektroenergetskim subjektom za opskrbu električnom energijom ako su takvi sustavi prilagođeni posebitostima poslovanja neovisnog operatora prijenosa ili vertikalno integriranog elektroenergetskog subjekta za opskrbu električnom energijom. Neovisni operator prijenosa mora se također suzdržati od zajedničkog korištenja informacijske infrastrukture sostalim dijelovima vertikalno integriranog elektroenergetskog subjekta za opskrbu električnom energijom, osim ako se takva infrastruktura 1) nalazi izvan poslovnih prostorija neovisnog operatora prijenosa i vertikalno integriranog subjekta te 2) pod uvjetom da uslugu korištenja takve infrastrukture pruža i njome upravlja tréca strana. Neovisni operator prijenosa i vertikalno integrirani elektroenergetski subjekt za opskrbu električnom energijom moraju osigurati da ne koriste usluge istih savjetnika ili vanjskih izvođača u pogledu informacijskih sustava i informacijske infrastrukture koja se nalazi u poslovnim ili uredskim prostorijama neovisnog operatora prijenosa ili vertikalno integriranog elektroenergetskog subjekta za opskrbu električnom energijom. Zbog ekonomskih i operativnih razloga zajedničko korištenje informacijskih sustava, informacijske infrastrukture te istih savjetnika ili vanjskih izvođača uobičajena je pojava kod povezanih društava. ${ }^{22}$ Njemački zakonodavac pritom razlikuje informacijske sustave i informacijske infrastrukture koja je zapravo razlikovanje između softvera i hardvera. ${ }^{23}$

Navedenom se odredbom nastoji spriječiti prijenos informacija između neovisnog operatora prijenosa i subjekta vertikalno integrirane strukture kada nema prepreka pristupu tim informacijama ili se one mogu savladati. ${ }^{24}$ Prema navedenom izričaju prvog dijela prve rečenice $\S 10$ a st. 5. EnWG-a proizlazi kako je zabranjeno „Zajedničko korištenje informacijskih sustava“ već kada se istim sustavom (softverom) istodobno koristi neovisni operator sustava i drugi subjekt vertikalno integrirane strukture bez obzira na to jesu li ti sustavi međusobno povezani i razmjenjuju podatke. Tom se stajalištu protivi dio njemačke pravne književnosti koji smatra kako ono nije razumno opravdano kada oba istovjetna sustava u vertikalno integriranim strukturama djeluju izolirano jedan od drugog, bez mogućnosti razmjene podataka. ${ }^{25}$

Bez obzira na izneseno, u nastavku prve rečenice njemački zakonodavac ipak ograničava takvu zabranu zajedničkoga korištenja informacijskih sustava. Predmetna odredba odstupa od konkretnoga izričaja čl. 17. st. 5. Direktive 2009/72/EZ, time što sadržajno ograničava zabranu zajedničkoga korištenja samo na one „sustave koji su prilagođeni posebnostima poslovanja“" neovisnog operatora prijenosa ili drugog subjekta vertikalno integrirane strukture. To znači da informacijski sustavi koji nisu

22 Knauff, u: Energiewirtschaftsgesetz, §10a EnWG Rbr. 15.

23 Säcker, Mohr, u: Berliner Kommentar zum Energierecht, §10a EnWG Rbr. 29; Hölscher, u: EnWG Energiewirtschaftsgesetz, §10a EnWG Rbr. 18, 21.

24 Knauff, u: Energiewirtschaftsgesetz, §10a EnWG Rbr. 16.

25 Hölscher, u: EnWG Energiewirtschaftsgesetz, §10a EnWG Rbr. 18. 
prilagođeni tim posebnostima ne potpadaju pod zabranu zajedničkog korištenja. To su, primjerice, uobičajeni računalni programi i aplikacije koje se koriste u svakodnevnom radu neovisno o predmetu poslovanja pojedinog društva (npr. Windows OS, MS Office te $S A P$ sustavi) kao i uobičajeni programi te aplikacije koji svoju primjenu nalaze samo u nekim granama gospodarstva unatoč tomu što se naknadno mogu prilagoditi potrebama korisnika. Drugim riječima, navedena zabrana obuhvaća samo one računalne programe i aplikacije kod kojih je prilagodba potrebama korisnika već obavljena. ${ }^{26}$ Predmetna zabrana obuhvaća programe i aplikacije koji su izrađeni na zahtjev korisnika te su time prilagođeni njegovim posebnim potrebama poslovanja (npr. softver vezan za nadzor i upravljanje elektroenergetskim sustavom). Zabrana se, stoga odnosi samo na programe i aplikacije kod kojih su istovjetne prilagodbe posebnim potrebama poslovanja. ${ }^{27}$ Korištenje istih informacijskih sustava koji su bili i u trenutku kada je došlo do, tzv. pravnog odvajanja neovisnog operatora prijenosa i drugog subjekta vertikalno integrirane strukture, ne opravdava doslovnu primjenu predmetne zabrane, već iziskuje poduzimanje mjera usmjerenih na postupnu zamjenu takvog informacijskog sustava drugim sustavom. ${ }^{28}$

U pogledu informacijske infrastrukture (hardvera) njemačko rješenje također odstupa od izričaja čl. 17. st. 5. Direktive 2009/72/EZ. Tako je načelno zabranjeno zajedničko korištenje informacijske infrastrukture neovisnog operatora prijenosa $\mathrm{s}$ ostalim subjektima vertikalno integrirane strukture. Zabrana se, međutim, ne odnosi na informacijsku infrastrukturu kojom se zajednički koriste neovisni operator prijenosa i drugi subjekt vertikalno integrirane strukture kada se: 1.) takva infrastruktura nalazi izvan poslovnih prostorija jednog i drugog, uz uvjet da 2.) uslugu korištenja takve infrastrukture pruža treća osoba koja ujedno njome i upravlja. Radi se o outsourcingu odjela informacijske infrastrukture prema nekom vanjskom pružatelju usluge. Takva treća osoba mora biti potpuno pravno neovisna o svim subjektima vertikalno integrirane strukture, dakle ne smije biti njezin dio niti imati članski (čak i manjinski) udio u subjektima vertikalno integrirane strukture (npr. koncerna). ${ }^{29}$ Prema stajalištu dijela njemačke pravne književnosti pod tim se, osim nepostojanja pravne, podrazumijeva i nepostojanje znatne gospodarske ovisnosti treće osobe prema subjektu vertikalno integrirane strukture..$^{30}$ Prema tom pravilu istom se informacijskom infrastrukturom koja se nalazi u istoj prostoriji može koristiti istodobno neovisni operator prijenosa i drugi subjekt vertikalno integrirane strukture ako niti jedan nema izravan pristup takvoj informacijskoj infrastrukturi. ${ }^{31}$ Uvjet za to je da tom infrastrukturom (npr.

26 Säcker, Mohr, u: Berliner Kommentar zum Energierecht, §10a EnWG, Rbr. 29; Hölscher, u: EnWG Energiewirtschaftsgesetz, §10a EnWG Rbr. 19. U tom smjeru vidi Knauff, u: Energiewirtschaftsgesetz, §10a EnWG, Rbr. 16.

27 Hölscher, u: EnWG Energiewirtschaftsgesetz, §10a EnWG, Rbr. 20.

28 Hölscher, u: EnWG Energiewirtschaftsgesetz, §10a EnWG, Rbr. 20.

29 Knauff, u: Energiewirtschaftsgesetz, §10a EnWG, Rbr. 17.

30 Smatra se, međutim, da postoji gospodarska ovisnost kada treća osoba, koja pruža uslugu korištenja svoje informacijske infrastrukture na tržištu, takvu uslugu uglavnom pruža drugim subjektima vertikalno integrirane strukture, na način da njen opstanak na tržištu ovisi o poslovanju sa subjektima vertikalno integrirane strukture. U tom smjeru vidi Knauff, u: Energiewirtschaftsgesetz, §10a EnWG, Rbr. 17.

31 Säcker, Mohr, u: Berliner Kommentar zum Energierecht, §10a EnWG, Rbr. 30; Hölscher, u: 
virtualnim i namjenskim poslužiteljima te bazama podataka) upravlja treća osoba u čiju djelatnost potpada najam informacijsko-tehnoloških resursa u tim i sličnim podatkovnim centrima. Pritom je trećoj osobi u poslovnom interesu osigurati tajnost pohranjenih podataka i zaštitu od neovlaštenog fizičkog pristupa korisnika usluge informacijsko-tehnološkim resursima, uključivo i subjektima vertikalno integrirane strukture koji se koriste tom uslugom. ${ }^{32}$

Konačno, odredba §10a st. 5. EnWG-a određuje i kako neovisni operator prijenosa i vertikalno integrirani subjekt ne mogu koristiti usluge istih savjetnika ili vanjskih izvođača u pogledu informacijskih sustava i informacijske infrastrukture koja se nalazi u prostoru neovisnog operatora prijenosa ili drugoga subjekta vertikalno integrirane strukture. Iako to nije izričito unio u zakonski tekst predmetne odredbe, njemački je zakonodavac jasno zauzeo stajalište u konačnom prijedlogu zakonskoga teksta kako korišteni izraz „savjetnici ili vanjski izvođači za informacijske sustave i informacijsku infrastrukturu“ podrazumijeva samo fizičke osobe, a ne i pravne (npr. trgovačko društvo). ${ }^{33}$ To znači kako ista pravna osoba, neovisno o tome djeluje li ona samo na domaćem tržištu ili izvan njega, može pružati usluge vezane za informacijske sustave i informacijsku infrastrukturu istodobno neovisnom operatoru prijenosa i drugom subjektu vertikalno integriranog sustava. Njemački zakonodavac pritom ističe kako takva pravna osoba mora poduzeti mjere koje onemogućuju da ista fizička osoba (npr. zaposlenik društva ili suradnik kao vanjski podugovaratelj tog društva) radi na poslovima za neovisnog operatora prijenosa i drugog subjekta vertikalno integrirane strukture. ${ }^{34}$ Drugim riječima, takva je pravna osoba obvezatna uspostaviti mjere u svojoj organizaciji i podjeli rada na način koji osigurava da jedna organizacijska jedinica ili suradnik (vanjski podugovaratelj) radi trajno samo za neovisnog operatora prijenosa, a ne i za ostale subjekte vertikalno integrirane strukture. Druga organizacijska jedinica savjetnika ili vanjskog izvođača uz iste uvjete može tada raditi za druge subjekte vertikalno integrirane strukture. Pritom nije dostatna samo uspostava formalnih mjera (engl. chinese walls ili fire walls) radi uspostave informacijsko-tehnološkog razdvajanja između pojedinih zaposlenika, odnosno vanjskih podugovaratelja, već se moraju poduzeti i organizacijske mjere. ${ }^{35}$ Tako, primjerice, savjetnik, odnosno vanjski

EnWG Energiewirtschaftsgesetz, §10a EnWG, Rbr. 21; Knauff, u: Energiewirtschaftsgesetz, $\S 10$ a EnWG, Rbr. 17.

32 Säcker, Mohr, u: Berliner Kommentar zum Energierecht, §10a EnWG, Rbr. 30; Knauff, u: Energiewirtschaftsgesetz, §10a EnWG, Rbr. 17. Nužno je upozoriti na moguće drukčije stajalište Europske komisije prema kojem općenito (kao što je šturo određeno i Direktivom 2009/72/EZ) neovisni operator prijenosa ne može dijeliti informacijske sustave ili informacijsku infrastrukturu s bilo kojim dijelom vertikalno integrirane strukture. Tako vidi Commission staff working paper, Interpretative note on Directive 2009/72/EC concerning common rules for the internal market in electricity and Directive 2009/73/EC concerning common rules for the internal market in natural gas, The Unbundling Regime, 22. January 2010, 16.

33 Deutscher Bundestag, Entwurf eines Gesetzes zur Neuregelung energiewirtschaftsrechtlicher Vorschriften, Drucksache 17/6072, 61; Hölscher, u: EnWG Energiewirtschaftsgesetz, §10a EnWG, Rbr. 22.

34 Deutscher Bundestag, Entwurf eines Gesetzes zur Neuregelung energiewirtschaftsrechtlicher Vorschriften, Drucksache 17/6072, 61.

35 Säcker, Mohr, u: Berliner Kommentar zum Energierecht, §10a EnWG Rbr. 31. U tom smjeru 
izvođač, kao pravna osoba, mora dokazati kako njegova unutrašnja organizacija elektroničke obrade podataka omogućuje samo osobama koje rade na projektu za neovisnog operatora prijenosa uvid u tekuće procese te da je osjetljiva dokumentacija čuvana ,pod ključem“s ograničenim pristupom. ${ }^{36}$

Njemački zakonodavac i njemačka pravna književnost izričito se ne dotiču niti problematiziraju pitanje nabave informacijske infrastrukture (hardvera) od vanjskih dobavljača. Za pretpostaviti je kako je to stoga što pitanje korištenja istih dobavljača informacijske infrastrukture (npr. računala, servera i druge specijalizirane informacijske opreme) neovisnog operatora prijenosa i drugog subjekta vertikalno integrirane strukture nije sporno u praksi. Može se stoga zaključiti kako predmetne odredbe EnWG-a ne zabranjuju korištenje istih vanjskih izvođača (dobavljača) za nabavku informacijske infrastrukture kao niti istodobno korištenje istih hardverskih konfiguracija (informacijske infrastrukture) neovisnog operatora prijenosa i drugoga subjekta vertikalnog integrirane strukture. Iz prethodno iznesenog proizlazi kako neovisni operator prijenosa može raditi s vanjskim izvođačima kojima se koristi i drugi subjekt vertikalno integrirane strukture, jer se zabrana korištenja istih vanjskih izvođača odnosi samo na fizičke osobe kao vanjskog izvođača ili fizičke osobe koje rade za vanjskog izvođača, a ne pravnu osobu vanjskog izvođača. ${ }^{37}$ Iznesena zabrana, štoviše, ima više smisla u odnosu na softver, iako je zamislivo kako se i hardver može prilagoditi posebnostima poslovanja neovisnog operatora prijenosa ili vertikalno integriranog subjekta. Može se zaključiti kako se u tim se situacijama, mogu koristiti isti dobavljači ili vanjski izvođači. No, ako je riječ o dobavljaču i vanjskom izvođaču koji ujedno prilagođava određenu informacijsku infrastrukturu posebnostima poslovanja neovisnog operatora prijenosa, tada on ili vanjski izvođač mora osigurati da na prilagodbama ne rade iste fizičke osobe (npr. zaposlenici i vanjski suradnici) koje obavljaju te i slične poslove i za ostale subjekte vertikalno integrirane strukture.

Takvo je izraženo stajalište njemačkoga zakonodavca posljedica upravo prepoznatih problema do kojih bi dovelo dosljedno transponiranje mjerodavne odredbe Direktive 2009/72/EZ. U slučaju uspostave apsolutne zabrane zajedničkoga korištenja usluga savjetnika i vanjskih izvođača, nadležni njemački regulator (njem. Bundesnetzagentur) smatra da bi se time većina savjetnika i vanjskih izvođača odlučila iz ekonomskih razloga za poslovnu suradnju s ostalim subjektima vertikalno integrirane strukture zbog njihove veličine, a time i većeg potencijala za ostvarenje prihoda. Time bi se nepotrebno ograničio manevarski prostor neovisnom operatoru prijenosa koji bi bio prisiljen raditi s nekolicinom preostalih savjetnika i vanjskih izvođača. Zbog mogućnosti smanjene zarade mogao bi povećati naknadu naplate za pružene usluge..$^{38}$ Problem postaje time još izraženiji uzme li se u obzir kako su IT usluge na tržištu električne energije visoko specijalizirane, zbog čega je i broj visoko specijaliziranih stručnih savjetnika i pružatelja usluga ograničen. Ta situacija, štoviše,

vidi Knauff, u: Energiewirtschaftsgesetz, §10a EnWG, Rbr. 18.

36 U tom smjeru vidi Säcker, Mohr, u: Berliner Kommentar zum Energierecht, §10a EnWG, Rbr. 31.

37 Tako vidi ranije pod istim poglavljem.

38 Odluka Bundesnetzagentur od 12. ožujka 2013. br. BK7-12-035, 37. Tako vidi Hölscher, u: EnWG Energiewirtschaftsgesetz, §10a EnWG, Rbr. 22. 
dovodi do povrede svrhe i ciljeva koji se žele postići pravnim rješenjima Direktive 2009/72/EZ o odvajanju operatora prijenosnog sustava od ostalih subjekta vertikalno integrirane strukture. Navedeno proizlazi iz činjenice da tada izborom savjetnika i vanjskih izvođača vladajuće društvo vertikalno integrirane strukture zapravo određuje koji su savjetnici i vanjski izvođači na tržištu uopće dostupni neovisnom operatoru prijenosa. $^{39}$ Takvim postupanjem vertikalno integrirane strukture ograničava se neovisnost i samostalnost neovisnog operatora prijenosa.

Odredbom $\S 10$ a st. 6. EnWG-a uređena su pravila o, tzv. prostornom razdvajanju, odnosno o zajedničkom korištenju uredskih i poslovnih prostorija, kao i sustava sigurnog pristupa između neovisnog operatora prijenosa i drugih dijelova vertikalno integrirane strukture. Smatra se kako se zajedničkim korištenjem uredskih i poslovnih prostorija povećava vjerojatnost da subjekti vertikalno integrirane strukture dođu do nedopuštenih informacija o djelatnostima neovisnog operatora prijenosa kao i da se koriste utjecajem radi ostvarivanja interesa ostatka vertikalno integrirane strukture. ${ }^{40}$ Stoga predmetna odredba određuje: Neovisni operator prijenosa $i$ drugi dijelovi vertikalno integriranog elektroenergetskog subjekta za opskrbu električnom energijom moraju se suzdržati od zajedničkog korištenja uredskih i poslovnih prostorija, uključivo i zajedničkog korištenja sustava sigurnog pristupa. Kao i u prethodnim slučajevima, navedena se zabrana odnosi na sve subjekte vertikalno integrirane strukture, uključivo i društva kćeri.

Prema toj odredbi nužno je razlikovati poslovne prostorije i sustav sigurnog pristupa tim prostorijama, koje koristi neovisni operator prijenosa od prostorija, i sustava sigurnog pristupa, koje koriste drugi subjekti vertikalno integrirane strukture. Pod zajedničkim korištenjem poslovnih prostorija neovisnog operatora prijenosa podrazumijeva se mogućnost pristupa tim prostorijama i neovisnog operatora prijenosa i drugoga subjekta vertikalno integrirane strukture. Iako bi to bilo idealno, imajući u vidu načelo proporcionalnosti kao i zahtjeve gospodarske razboritosti, to ne znači kako se poslovne prostorije neovisnog operatora prijenosa i drugih subjekata vertikalno integrirane strukture moraju nalaziti u različitim nekretninama (npr. na različitim lokacijama ili u različitim poslovnim zgradama). ${ }^{41}$ Bilo bi dostatno da su poslovne prostorije oba subjekta $\mathrm{u}$ istoj nekretnini (npr. $\mathrm{u}$ istoj poslovnoj zgradi ili čak $\mathrm{u}$ istom posebnom dijelu nekretnine) strogo odvojene, npr. različitim sustavima sigurnog pristupa. ${ }^{42}$ Takva zabrana ne znači niti kako je subjekt vertikalno integrirane

39 Odluku Bundesnetzagentur od 12. ožujka 2013. br. BK7-12-035, 38; Säcker, Mohr, u: Berliner Kommentar zum Energierecht, §10a EnWG, Rbr. 31.

40 Knauff, u: Energiewirtschaftsgesetz, §10a EnWG, Rbr. 19.

41 Säcker, Mohr, u: Berliner Kommentar zum Energierecht, §10a EnWG, Rbr. 32; Hölscher, u: EnWG Energiewirtschaftsgesetz, §10a EnWG, Rbr. 24-25. Nužno je opet upozoriti na moguće drukčije stajalište Europske komisije prema kojem općenito (kao što je šturo određeno i Direktivom 2009/72/EZ) neovisni operator prijenosa ne može dijeliti fizičke prostore (nekretnine?) s bilo kojim dijelom vertikalno integrirane strukture. Tako vidi Commission staff working paper, Interpretative note on Directive 2009/72/EC concerning common rules for the internal market in electricity and Directive 2009/73/EC concerning common rules for the internal market in natural gas, The Unbundling Regime, 22. January 2010, 16.

42 Hölscher, u: EnWG Energiewirtschaftsgesetz, §10a EnWG Rbr. 25; Knauff, u: Energiewirtschaftsgesetz, §10a EnWG, Rbr. 19. 
strukture spriječen u davanje zakupa svojih poslovnih prostorija neovisnom operatoru prijenosa. No, ako dođe do toga, tada ugovor o zakupu mora biti sklopljen prema uobičajenim tržišnim uvjetima. ${ }^{43}$

Iako neovisni operator prijenosa $\mathrm{i}$ drugi subjekti vertikalno integrirane strukture ne koriste zajednički uredske i poslovne prostore, s tim se korištenjem zajedničkih prostora, a time i zabranom takvog korištenja izjednačava i zabrana zajedničkog korištenja sustava sigurnog pristupa. Korištenjem sustava sigurnog pristupa podrazumijeva se korištenje sustava pristupa (npr. mehaničkih ili elektronskih) koji zaposlenicima ostalih subjekata vertikalno integrirane strukture onemogućuje pristup poslovnim prostorijama neovisnog operatora prijenosa. ${ }^{44}$ Zabrana zajedničkog korištenja sustava sigurnog pristupa stoga podrazumijeva mjere koje moraju onemogućiti da zaposlenik drugoga subjekta vertikalno integrirane strukture ima nekontroliran i nenadziran pristup poslovnim prostorijama neovisnog operatora prijenosa i obratno. Ta zabrana ne obuhvaća i zajedničko korištenje usluga iste zaštitarske pravne osobe ako se poduzmu mjere koje onemogućuju prijenos povjerljivih informacija s neovisnog operatora prijenosa prema drugim subjektima vertikalno integrirane strukture, kao i pridržavanje osnovnih načela o čuvanju tajnosti podataka (npr. osiguravanjem da poslove zaštite obavljaju različite fizičke osobe ili da te osobe nemaju pristup prostorijama ili sustavima u kojima se nalaze osjetljive informacije). ${ }^{45}$

\subsection{Francuska poredbeno pravna rješenja}

Odredba čl. 17. st. 5. Direktive 2009/72/EZ transponirana je u francusko pravo odredbama L111-15 i L111-16 Zakona o energetici (Code de l'énergie, dalje: CdE). ${ }^{46}$ Kao i kod njemačkoga zakonodavca, u trenutku pisanja ovog rada odredbe Direktive 2019/944 nisu bile transponirane u francusko nacionalno zakonodavstvo. No, može se očekivati da se postojeća pravila o neovisnom operatoru prijenosa pri transponiranju neće sadržajno mijenjati. Tako odredba L111-16 st. 1. CdE određuje: Niti jedan drugi subjekt vertikalno integrirane strukture definirane čl. L111-10 ne može ostvariti pristup aktivnostima automatizirane obrade podataka o radu, razvoju i održavanju sustava neovisnog operatora prijenosa niti sredstvima koje neovisni operator prijenosa koristi za izvršavanje tih aktivnosti. U tom cilju, sustav informacijske tehnologije neovisnog operatora prijenosa strogo je odvojen od sustava koje koriste drugi subjekti vertikalno integrirane strukture na način da niti jednom zaposleniku tih drugih subjekata kao niti jednom njihovom pružatelju usluga nije moguć pristup bazama podataka neovisnog operatora prijenosa. Nadalje odredba L111-16 st. 2. CdE određuje: Prilikom sklapanja ugovora o obavljanju poslova na automatiziranim sustavima za obradu podataka neovisnog operatora prijenosa sa sungovarateljima koji pružaju usluge iste vrste drugim subjektima vertikalno integrirane strukture, neovisni operator prijenosa dužan je osigurati da sungovaratelji poštuju pravila o

43 Säcker, Mohr, u: Berliner Kommentar zum Energierecht, §10a EnWG, Rbr. 33.

44 Knauff, u: Energiewirtschaftsgesetz, §10a EnWG, Rbr. 19.

45 Säcker, Mohr, u: Berliner Kommentar zum Energierecht, §10a EnWG, Rbr. 33.

46 Code de l'énergie, pristup 15. srpnja 2020., https://www.legifrance.gouv.fr/. 
povjerljivosti. U takvom slučaju o sklopljenim ugovorima neovisni operator prijenosa dužan je izvijestiti nadležnog regulatora.

Iz tako transponiranog čl. 17. st. 5. Direktive 2009/72/EZ proizlazi težnja francuskoga zakonodavca ispunjavanje svrhe odredbi o odvajanju uz razradu modela na način da drugim stavkom određuje iznimku od stroge obveze odvajanja iz prvog stavka uz uvjet poštovanja povjerljivosti podataka te uz propisanu obvezu prijave nadležnom regulatoru. Naime, prvim je stavkom određena načelna zabrana pristupa informacijskim sustavima (sustavi automatizirane obrade podataka o radu, razvoju i održavanju odnosno softver) te sredstvima koja se koriste za pristup (hardver) svim onim trećim osobama uključujući i njihove zaposlenike te vanjske suradnike, koji takve usluge već pružaju nekom od drugih subjekata unutar vertikalno integrirane strukture. Sadržaj se ovog stavka preklapa sa sadržajem odredbe čl. 17. st. 5. Direktive 2009/72/EZ, utoliko što zabranjuje uvid u informacijske sustave ili informacijsku infrastrukturu te sustav sigurnog pristupa neovisnog operatora prijenosa bilo kojem drugom subjektu unutar vertikalno integrirane strukture ili njegovom vanjskom izvođaču, međutim, ne zabranjuje korištenje istih fizičkih prostora. Iznesena je odredba ublažena dodatno drugim stavkom istog članka, kojim francuski zakonodavac postavlja iznimku od strogih odredbi odvajanja tako da ipak dopušta istodobno korištenje istih savjetnika ili vanjskih izvođača neovisnog operatora prijenosa i drugog subjekta vertikalno integrirane strukture, ako neovisni operator prijenosa osigura strogo poštovanje povjerljivosti. Takvo se poštovanje osigurava određivanjem obveze neovisnom operatoru prijenosa, da korištenje usluga vanjskih savjetnika i izvođača koji istodobno pruža takve usluge drugom subjektu vertikalno integrirane strukture, prijavi nadležnom regulatoru.

Iz navedenih odredaba CdE-a proizlazi težnja francuskoga zakonodavca da odredbu čl. 17. st. 5. Direktive 2009/72/EZ tumači suženo kako bi ih prilagodio posebnostima na nacionalnom tržištu. Pritom poštuje namjeru europskoga zakonodavca o uređivanju sustava na način kojim se osigurava učinkovito odvajanje neovisnog operatora prijenosa od utjecaja politika vladajućeg subjekta vertikalno integrirane strukture. Francuski zakonodavac time olakšava pristup visoko specijaliziranim stručnjacima koji pružaju IT usluge te olakšava natjecanje na mjerodavnom tržištu. Istodobno osigurava da korištenje usluga istih savjetnika ili vanjskih izvođača unutar vertikalno integriranog subjekta ne spriječi učinkovito odvajanje neovisnog operatora prijenosa od ostatka vertikalno integrirane strukture.

\section{UMJESTO ZAKLJUČKA - DE LEGE FERENDA PRIJEDLOG NOVIH ZAKONSKIH ODREDABA KOJIMA SE PRENOSE RAZMATRANE ODREDBE EUROPSKOGA PRAVA U HRVATSKO PRAVO}

Odredba čl. 17. st. 5. Direktive 2009/72/EZ transponirana je u hrvatsko pravo u čl. 18. st. 7. i 8. ZoTEE-a koji je stupio na snagu 2013. Time je uspostavljen osnovni zakonski i institucijski okvir za restrukturiranje i reorganizaciju domaćega energetskog sektora, liberalizaciju tržišta, regulaciju energetskih djelatnosti i sl. Tako 
ZoTEE predmetnim odredbama određuje:

(7) Neovisni operator prijenosa ne smije zajednički dijeliti informatičke sustave ili opremu, poslovne prostore $i$ sustave sigurnog pristupa s bilo kojim dijelom vertikalno integriranog subjekta niti zajednički koristiti usluge istih savjetnika ili vanjskih izvođača za informatičke sustave ili opremu ili sustave sigurnog pristupa.

(8) Neovisni operator prijenosa mora dati jamstvo da glede informatičke opreme i sustava kontrole pristupa zajednički ne surađuje s istim savjetnicima i vanjskim pružateljima usluga kao i vertikalno integrirani subjekt.

U odnosu na odgovarajuće odredbe Direktive 2009/72/EZ, a time i Direktive 2019/944, može se zaključiti kako je domaći zakonodavac sadržajno potpuno u čl. 18. st. 7. ZoTEE pratio sadržaj čl. 17. st. 5. Direktive 2009/72/EZ. Odredbom čl. 18. st. 8. ZoTEE-a dijelom je odstupio od onog što je sadržajno određeno Direktivom 2009/72/EZ time što je propisao dodatne uvjete vezane za zajedničko korištenje istih savjetnika i vanjskih izvođača (uvjet davanja jamstva).

Imajući u vidu nedostatke koji su se pokazali u primjeni tako transponiranih odredbi ZoTEE-a u kontekstu ograničenog pristupa uslugama na IT tržištu, a uzimajući u obzir usporedna pravna rješenja država članica koje koriste model neovisnog operatora prijenosa (ITO model odvajanja), pri transponiranju Direktive 2019/944 u domaće zakonodavstvo predlaže se odredbe čl. 18. st. 7. i 8. ZoTEE-a izmijeniti na sljedeći način:

(7) Neovisni operator prijenosa i vertikalno integrirani subjekt ili neki njegov dio:

1. ne smiju zajednički dijeliti informacijske sustave (softver) ako su takvi sustavi prilagođeni posebitostima poslovanja neovisnog operatora prijenosa ili vertikalno integriranog subjekta ili nekog njegovog dijela;

2. ne smiju zajednički dijeliti računalnu, mrě̌nu i sigurnosnu infrastrukturu (hardver), osim ako se takva infrastruktura nalazi izvan njihovih poslovnih prostorija te njome upravlja treća strana koja na tržištu pruža usluge korištenja informacijskotehnoloških resursa;

3. ne smiju zajednički dijeliti uredske i poslovne prostorije te sustave sigurnog pristupa.

4. ne smiju koristiti usluge istih savjetnika ili vanjskih izvođača za pružanje usluga vezanih za informacijske sustave (softver) ili računalnu, mrežnu i sigurnosnu infrastrukturu (hardver) ili sustave sigurnog pristupa. Ova se zabrana odnosi samo na fizičke osobe koje rade za takve savjetnike ili vanjske izvođače (npr. zaposlenike $i$ suugovaratelje savjetnika ili vanjskog izvođača pravne osobe) i na fizičke osobe koje pružaju takve usluge kao samostalni savjetnici $i$ vanjski izvođači. Ova se zabrana ne odnosi na isporuku računalne, mrežne i sigurnosne infrastrukture (hardvera) neovisnom operatoru prijenosa bez pružanja predmetnih usluga.

(8) Sungovaratelj neovisnog operatora prijenosa mora prilikom sklapanja ugovora o obavljanju djelatnosti iz st. 7. t. 2. $i$ 4. ovog članka uspostaviti organizacijske mjere koje osiguravaju da isti zaposlenik ili vanjski suradnik koji radi na izvršenju ugovorenih poslova za neovisnog operatora prijenosa trajno ne radi na takvim i sličnim poslovima za vertikalno integriranog subjekta ili neki njegovi dio. 
Zaposlenici $i$ vanjski suradnici suugovaratelja neovisnog operatora prijenosa koji rade na poslovima za neovisnog operatora prijenosa moraju povjerljivo postupati $s$ komercijalno osjetljivim podacima i informacijama, a osobito ih ne smiju dijeliti s vertikalno integriranim subjektom.

Tim se rješenjem ostvaruje cilj i svrha odvajanja u vidu poštovanja samostalnosti i neovisnosti operatora prijenosa $u$ odnosu na ostale subjekte vertikalno integrirane strukture. Imajući u vidu ograničenosti domaćeg tržišta istodobno se neovisnom operatoru prijenosa omogućuje pristup pružateljima visoko specijaliziranih IT usluga. Uzor pri izradi ovoga prijedloga odredaba postojeća su rješenja ZoTEE-a, ali i prethodno prikazana poredbenopravna rješenja njemačkoga prava. Njemačko pravo pripada krugu europskih pravnih sustava kojima se temeljito uređuju pravila o tržištu električne energije koja mogu poslužiti kao uzor pri izradi i razvoju odgovarajućega domaćeg pravnog sustava. Pritom ne treba zanemariti niti činjenicu kako njemačko pravo pripada germanskom kontinentalnom pravnom krugu kojem pripada i hrvatsko pravo, zbog čega ne čudi što je domaći zakonodavac brojna druga domaća pravna pravila izradio po uzoru na njemačko pravo (npr. iz područja prava društava i stečajnog prava). Uredi li se hrvatsko energetsko pravo po uzoru na njemačko pravo, u primjeni i tumačenju tako uređenih normi hrvatskoga energetskog prava svakako može pomoći bogata i ustaljena praksa njemačkoga regulatora (njem. Bundesnetzagentur), ali i praksa njemačkih sudova. Naime, u njoj se odlučivalo o pitanjima koja se kod nas još nisu postavila ili su se tek počela pojavljivati u svakodnevnom poslovanju. Također, spomenuta je praksa praćena brojnim radovima njemačke pravne književnosti koji nam pritom, uz odgovarajuću razinu opreza i kritičnosti, također mogu pružiti jednostavan i opsežan pristup izvorima prava za probleme koje nalazimo i koji će se tek pojaviti na domaćem tržištu. S obzirom na odstupanja mjerodavnih odredbi njemačkoga EnWG-a od izričitog sadržaja mjerodavnih odredbi Direktive 2009/72/EZ, upućuje se na prethodno izneseno stajalište kako one uvažaju svrhu i cilj koji se žele postići Direktivom. Pritom ne treba zanemariti niti razloge koji su u njemačkom pravu doveli do takvog odstupanja i detaljnijeg uređenja pravila o zajedničkom korištenju informacijskih sustava i infrastrukture, istih savjetnika i vanjskih izvođača. Nema dvojbe kako je njemačko tržište IT usluga bitno veće od domaćeg tržišta, no unatoč tomu, čak je i njemački zakonodavac prepoznao potrebu ograničavanja apsolutne zabrane korištenja istih savjetnika ili vanjskih izvođača određene Direktivom 2009/72/ EZ. Stoga je, radi očuvanja cilja i svrhe predmetne direktive, odnosno sprječavanja eventualnih zloupotreba te očuvanja neovisnosti i samostalnosti neovisnog operatora prijenosa, odredio uspostavu odgovarajućih kompenzacijskih (organizacijskih) mjera. Navedena rješenja njemačkoga prava, stoga mogu biti primjer i hrvatskom zakonodavcu s obzirom na način transponiranja pravila Direktive 2009/72/EZ i Direktive 2019/944 u nacionalno pravo države članice. Pored pravila njemačkoga prava, uzor pri izradi danoga prijedloga pružilo je i francusko pravo prema kojem je, kao i u Hrvatskoj, odvajanje operatora prijenosnog sustava provedeno putem modela neovisnog operatora prijenosa.

Prijedlog čl. 18. st. 7. raspisan je po točkama u odnosu na informacijske sustave (softver), informacijsku opremu (hardver), uredske i poslovne prostorije, sustav 
sigurnog pristupa te korištenje usluga istih savjetnika i vanjskih izvođača. Time se omogućuje formuliranje načelne zabrane dijeljenja i korištenja postavljanjem uvjeta, odnosno iznimki kojima se takva zabrana prilagođava zadatostima domaćeg tržišta po uzoru na njemački model. Konkretno, bez obzira na načelnu zabranu, informacijski sustavi moći će se dijeliti između neovisnog operatora prijenosa i subjekta vertikalno integrirane strukture ako nisu prilagođeni posebnostima njihova poslovanja (npr. uobičajeni računalni programi koji se koriste u svakodnevnom poslovanju te nisu izrađeni na zahtjev korisnika i prilagođeni njegovom poslovanju). Informacijska infrastruktura moći će se dijeliti ako se nalazi izvan poslovnih prostorija neovisnog operatora prijenosa i subjekta vertikalno integrirane strukture te ako njome upravlja treća osoba. Korištenje istih vanjskih savjetnika i izvođača ograničit će se na savjetnike i vanjske izvođače fizičke osobe.

Kako bi se osiguralo da se takvim prilagođavanjem posebnostima domaćeg tržišta ne ugrozi svrha odvajanja operatora prijenosnog sustava od vertikalno integrirane strukture, čl. 18. st. 8. uređuje po uzoru na njemački primjer obvezu prethodne uspostave organizacijskih mjera $u$ istoj pravnoj osobi suugovaratelja neovisnog operatora prijenosa. Te mjere moraju onemogućiti da isti zaposlenici i vanjski suradnici suugovaratelja neovisnog operatora prijenosa, koji rade na poslovima za neovisnog operatora prijenosa (npr. IT stručnjaci koji rade na informacijskog sustava za neovisnog operatora prijenosa), rade i za druge subjekte vertikalno integrirane strukture. Uz to, po uzoru na francuski model uređuje se i obveza neovisnog operatora prijenosa osigurati poštivanje pravila o povjerljivosti. Tako korištena kombinacija njemačkog i francuskog rješenja istodobno osigurava veću prilagodljivost sustava i poštovanja svrhe i cilja Direktive 2009/72/EZ. Izneseni prijedlog pritom odstupa od konkretnog izričaja tih poredbenopravnih rješenja, ali uz očuvanje njihova smisla i svrhe, i to samo onoliko koliko je to potrebno radi postizanja bolje jasnoće i veće pravne sigurnosti u eventualnoj primjeni tako predloženih pravnih rješenja.

\section{LITERATURA}

1. Britz, Gabriele, Johannes, Hellermann i Georg, Hermes, eds. EnWG Energiewirtschaftsgesetz. 3. Aufl. München: C.H. Beck, 2015.

2. CEER, Status Review on the Implementation of Transmission System Operators' Unbundling Provisions of the 3rd Energy Package, CEER Status Review, Ref: C15LTF-43-04, 1 April 2016, Updated on 28 April 2016.

3. Code de l'énergie, pristup 15. srpnja 2020., https://www.legifrance.gouv.fr/.

4. Commission staff working paper, Interpretative note on Directive 2009/72/EC concerning common rules for the internal market in electricity and Directive 2009/73/EC concerning common rules for the internal market in natural gas, The Unbundling Regime, 22. January 2010 .

5. Deutscher Bundestag, Entwurf eines Gesetzes zur Neuregelung energiewirtschaftsrechtlicher Vorschriften, Drucksache 17/6072.

6. Direktiva 2009/72/EZ Europskog parlamenta i Vijeća od 13. srpnja 2009. o zajedničkim pravilima za unutarnje tržište električne energije i stavljanju izvan snage Direktive 2003/54/EZ, SL 211, 14.8.2009. 
7. Direktiva 2019/944 Europskog parlamenta i Vijeća od 5. lipnja 2019. o zajedničkim pravilima za unutarnje tržište električne energije i izmjeni Direktive 2012/27/EU, SL 158, 14.6.2019.

8. Energiewirtschaftsgesetz vom 7. Juli 2005 (BGBl. I S. 1970, 3621), das zuletzt durch Artikel 3 des Gesetzes vom 17. Dezember 2018 (BGBl. I S. 2549) geändert worden ist.

9. European Commission, An Energy Policy for Europe, 10 January 2007, COM (2006) 841 final.

10. European Commission, Commission Staff Working Document - Report on the ITO Model, 13 October 2014, SWD(2014) 312 final.

11. Kment, Martin, ed., Energiewirtschaftsgesetz. 2. Aufl. Baden-Baden: Nomos, 2019.

12. Odluka Bundesnetzagentur od 12. ožujka 2013. br. BK7-12-035.

13. Säcker, Franz Jürgen, ed., Berliner Kommentar zum Energierecht. Bd. 1. (Halbbd. 1), 4. Aufl. Berlin: R\&W 2019.

14. Tilman, Michael Dralle. Ownership Unbundling and Related Measures in the EU Energy Sector. Cham: Springer, 2018.

15. Uredba o kriterijima za stjecanje statusa ugroženog kupca energije iz umreženih sustava, Narodne novine, br. 95/15.

16. Zakon o regulaciji energetskih aktivnosti, Narodne novine, br. 120/12., 68/18.

17. Zakon o tržištu električne energije, Narodne novine, br. 22/13., 102/15., 68/18., 52/19. 


\author{
Tomislav Jakšić* \\ Daša Vrzić**
}

Summary

\title{
PROPOSAL OF NEW PROVISIONS AMENDING THE ELECTRICITY ENERGY MARKET ACT RELATING TO THE SHARING OF PHYISICAL PREMISES, IT EQUIPMENT AND IT SYSTEMS AS WELL AS THE USE OF SAME IT SERVICE PROVIDERS AND SUPPLIERS OF IT EQUIPMENT BETWEEN THE INDEPENDENT TRANSMISSION OPERATOR AND OTHER PARTS OF THE VERTICALLY INTEGRATED UNDERTAKING
}

\begin{abstract}
Independent transmission operator represents one of three possible approaches to unbundling of the transmission system operator from the other parts of the vertically integrated undertaking. Croatian independent transmission operator is separated from the vertically integrated undertaking based on the independent transmission operator unbundling model. Considering the impending wider need to amend the Croatian legislative framework concerning the electrical energy market this paper critically examines certain problematic aspects of such unbundling process, for example, the regulation of shared use of IT systems (software), computer, network and security infrastructure (hardware) as well as services provided by the same consultants and external contractors. After analysis of existing European legal rules and national rules of comparable member states the paper provides concrete de lege ferenda suggestions for possible future regulation of the considered unbundling aspects.
\end{abstract}

Keywords: independent transmission operator; electricity energy market; transmission system operator; group of companies.

\footnotetext{
* Tomislav Jakšić, Ph.D., Associate Professor, Faculty of Law, University of Zagreb; tomislav. jaksic@pravo.hr.

** Daša Vrzić, mag. iur., Lawyer in Zagreb; dasa.vrzic@gmail.com.
} 


\title{
VORSCHLAG ZUR ÄNDERUNG DES STROMMARKTGESETZES IN HINSICHT AUF TEILUNG DER GESCHÄFTSRÄUME, IT-AUSSTATTUNG UND SYSTEME, SOWIE BENUTZUNG DERSELBEN ANBIETER VON IT-DIENSTLEISTUNGEN UND LIEFERANTEN VON IT-AUSSTATTUNG ZWISCHEN UNABHÄNGIGEN ÜBERTRAGUNGSBETREIBERN UND ANDEREN SUBJEKTEN EINER VERTIKAL INTEGRIERTEN STRUKTUR
}

\begin{abstract}
Unabhängige Übertragungsbetreiber zählen zu den drei Typen der Teilung der Übertragungsnetzbetreiber von anderen Subjekten innerhalb einer vertikal integrierten Struktur. Der kroatische Übertragungsnetzbetreiber ist von der vertikalen Integration durch die Anwendung des unabhängigen Übertragungsbetreibermodells abgetrennt. In Anbetracht des sich annähernden Bedarfs der breiten Änderungen und Ergänzungen der Gesetzgebung zum Strommarkt, werden bestimmte Problemaspekte dieser Trennung, wie die Regel zur Informationssystemteilung (Software), Computer, Netz und Sicherheitsinfrastruktur (Hardware), sowie der Benutzung von Diensten derselben Berater und externen Auftragnehmer genauer unter die Lupe genommen. Nach der durchgeführten Analyse vorhandener europäischen Regelungen und Gesetzgebungen vergleichbarer Mitgliedstaaten, werden konkrete de lege ferenda Vorschläge für eventuelle künftige Regelung der betrachteten Aspekte der Trennung des unabhängigen Übertragungsbetreibers von der restlichen vertikal integrierten Struktur gemacht.
\end{abstract}

Schlüsselwörter: unabhängige Übertragungsbetreiber; Strommarkt; gebundene Unternehmen; Übertragungsnetzbetreibe. 
Riassunto

\section{PROPOSTA PER LA MODIFICAZIONE DELLE DISPOSIZIONI DELLA LEGGE SUL MERCATO DELL'ENERGIA ELETTRICA SULLA CONDIVISIONE DEGLI UFFICI, DELLE APPARECCHIATURE IT E DEI SISTEMI IT COME ANCHE SULL'USO DEGLI STESSI PRESTATORI DI SERVIZIO IT E DEI FORNITORI DELLE APPARECCHIATURE IT TRA IL GESTORE DI TRASMISSIONE INDIPENDENTE E GLI ALTRI SOGGETTI NELLA STRUTTURA INTEGRATA VERTICALMENTE}

Il gestore di trasmissione indipendente è uno dei tre possibili modi di separazione del gestore dei sistemi di trasmissione dagli altri soggetti nella struttura integrata verticalmente. Il gestore croato dei sistemi di trasmissione è separato dalla struttura integrata verticalmente proprio con l'applicazione del modello del gestore di trasmissione indipendente. Tenendo conto della futura necessità di vasti emendamenti del quadro normativo nazionale che regola il mercato dell'energia elettrica, nel lavoro si esaminano criticamente certi aspetti problematici di questa separazione, ad esempio, le regole sulla condivisione dei sistemi informatici (software), delle infrastrutture informatiche, di rete e di sicurezza (hardware), come anche quelle sull'uso dei servizi degli stessi consiglieri e degli stessi esecutori esterni. Dopo l'analisi condotta sulle regole europee esistenti, come anche sulle soluzioni normative degli stati membri comparabili, il lavoro fornisce proposte concrete de lege ferenda per la possibile futura regolazione normativa degli aspetti esaminati della separazione del gestore di trasmissione indipendente dal resto della struttura integrata verticalmente.

Parole chiave: gestore di trasmissione indipendente; mercato dell'energia elettrica; gestore dei sistemi di trasmissione; società collegate. 